УДК 004.738.5:81'243(045)=111

DOI: https://doi.org/10.35387/od.2(16).2019.131-137

Feltsan Inna - Senior Lecturer, Department of English Philology and Methodology of Foreign Language Teaching Methods, Mukachevo State University

ORCID ID: https://orcid.org/0000-0003-4169-9922

E-mail: innafeltsan@gmail.com

\title{
SOCIAL NETWORKS AS A TOOL FOR DEVELOPMENT FOREING GRAMMAR COMPETENCE OF UNIVERSITY STUDENTS
}

Abstract. It has been commonly agreed that social networks is an educational tool related to interests and needs of a modern student. We may use it as a connector between participants of educational process: teachers may reach their students outside limited classroom activity and motivate them to further study in a non-formal atmosphere.

The article discusses possibilities of using social networks (Facebook) and digital applications (like, Viber) to develop grammar competence of students through blogging, texting, posting. Having organized a small focus group, we were able to: define functions and skills which are required when you enter networks for educational purposes; understand the drawbacks of using social networks and describe the support expected from a teacher; advise on the pace and tasks used in virtual classes. Dynamics of cosmopolitan societies demand knowledge of international communicative ethics which, due to IT progress, is required during e-mailing, on-line discussions and meetings, participation in distant conferences. Modern student is a researcher who can do both - collect and share information with the outer world.

There's also much space for personal development: students learn to promote their skills, communicate in virtual profession-oriented environment, form cross-cultural verbal literacy, improve soft skills and interpersonal cooperation, analyze and correct own grammar mistakes as well as accumulate experience of other group members. Knowing the methodology of up-to-date practices, teacher can motivate to educative on-line communication: writing blogs, posting on latest events, commenting to daily tasks in viber-community. Active learning demonstrates results of study immediately - staying verbally active 24/7, students see the perspective of own future mobility.

We have concluded that there's an urge necessity for professional upgrade of teachers, as using social networks for specific educative purposes demands personal mobility, compute proficiency, readiness to work outside formal classroom, responsibility for creation of informal study material and content choice, psychological competence, people skills.

Key words: social networks, mobility, modern educational tool, digital competence, blogging, virtual class.

Фельцан Інна Михайлівна - старший викладач кафеедри 
англійської фрілології та методики викладання іноземних мов Мукачівського державного університету

ORCID ID: https://orcid.org/0000-0003-4169-9922

E-mail: innafeltsan@gmail.com

\title{
СОЦІАЛЬНІ МЕРЕЖІ ЯК ІНСТРУМЕНТ РОЗВИТКУ ІНШОМОВНОÏ ГРАМАТИЧНОÏ КОМПЕТЕНТНОСТІ СТУДЕНТІВ ЗАКЛАДІВ ВИЩОЇ ОСВІТИ
}

\begin{abstract}
Анотація. На сучасному етапі розвитку технологій міжособистісного спілкування, все частіше лунає думка про те, що соціальні мережі є освітнім інструментом, що відповідає інтересам та потребам сучасного студента. Залучення до навчання за межами аудиторії належить до пріоритетів освіти, а необхідність створення віртуального навчального середовища зазначена в національних стандартах.

Формування граматичної компетентності з іноземної мови відноситься до найскладніших аспектів навчання, проте використання сучасних інтернет-платформ прискорює цей процес та мотивує до самостійного самовдосконалення - студент розуміє де $і$ як йому доведеться проявити іншомовну граматичну компетентність в майбутньому.

Потениійні можливості, доступні сучасному викладачеві іноземної мови, значно прискорюють процес навчання та підвищують його ефективність. Блоги, інтерв'ю наживо, відкриті лекції відомих науковців, віртуальні подорожі - представляють інформаційні матеріали у цікавій, близькій до студентства формі, що є невід'ємною складовою методики формування іншомовної компетентності тих, хто вчиться не тільки добувати інформацію, а й оперувати нею з метою досягнення профресійних чи особистих цілей. У світовій освітній практиці інформаційно-комунікаційні технології розглядаються як якісно новий спосіб формування навичок.

Доступність інформаційних платформ відкриває можливості до групового та самостійного навчання, проте з координуванням та рекомендаціями від викладача: чим молодший студент - тим активнішої підтримки потребує; студентам, які продовжують навчання після довгої перерви, потрібне додаткове консультування щодо використання інтернет-технологій у навчанні. Саме на педагога покладено відповідальність за добір матеріалів, які б відповідали поставленим цілям та не порушували принцип відповідності змісту меті, розуміння якого приходить з досвідом та профресіоналізмом.

Організувавши фокус-групу, ми отримали можливість: визначити функції та навички необхідні викладачу під час використання соціальних мереж в освітніх цілях; зрозуміти потенційні помилки та охарактеризувати підтримку, яку очікують від педагога у віртуальному
\end{abstract}


навчальному середовищі; рекомендувати педагогічний темп та завдання, які використовують у віртуальних аудиторіях.

Ключові слова: соціальні мережі, мобільність, сучасний навчальний метод, цифрова компетентність, блог, віртуальний клас.

Introduction. Modern educational needs have been defined by demands and practical interests of those who consider education as a tool for achieving specified goals - professional and personal. Use of mobile social communities in study creates space for comfortable and mobile way of achieving accomplishments, which would correspond to busy lifestyle of students occupied with part-time jobs, extracurricular activities and family responsibilities.

The development of information technology is a continuous process that accompanies modern person throughout life and creates additional opportunities for cognition and interaction in society. It has been emphasized that virtual education contributes to the development of qualitatively new content characteristics, in the context of which the symbolic image of the modern personality is being formed (Lukianova, Tovkanets, Sotska, \& Trynus, 2019).

The analysis of recent research. Modern methods use other scientific possibilities to investigate such scientific researches as N. Bilan, O. Vashchylo, N. Divinska, N. Prevozniuk. According to specialists who work in another way, they can be sure of D. Demchenko, O. lovenko, T. Koroleva.

Research findings. The opportunities available to modern foreign language teacher greatly accelerate the learning process and increase its effectiveness. Blogs, interviews, open lectures by well-recognized scientists, virtual travels - shape the content in a live and engaging manner, which is close to the studentship, and is an integral part of development foreign language competence of those who learn not only to passively acquire information, but also operate it for professional or personal needs. In the international educational practice, information technologies are considered as a new way of imparting knowledge.

Furthermore, apart from its primary task (to satisfy the educational needs of socially active people), digital education may serve as a tool for teachers to develop grammar accuracy of students. The first thing a lecturer should do is to create the best condition for learning, offer the environment which provides opportunities and stimulates students to interact in English, develop written self-confidence (Salikin \& Bin Tahir, 2017). Working online fosters a sense of global interaction. Students can communicate with their teachers and friends through writing blogs or Facebook posts; they can read and comment directly, which enhances outside classroom activity and motivates to dialogue with a teacher, upgrades knowledge, helps to build confidence, trains thinking, expands vocabulary (Yunus, Salehi, \& Chenzi, 2012).

Generally, activities performed at computers or mobile devices seem more enjoyable and motivating for modern people. A suitable implementation of 
web techniques can lead to the development of skills related to search and selection of information (Rodríguez Sánchez, 2017).

At present, there are a great number of people who spend long hours surfing the internet pages, reading unnecessary information that steals attention, energy and time. According to Mashable, Facebook is the most used social media tool in higher education (Newnam, 2012); the average person spends over four hours a day on their device (Curtin, 2018); on average, people are online 24 hours a week, twice as long as 10 years ago, the young also check their phones every 8.6 minutes (Hymas, 2018).

Despite some researchers who discuss drawbacks of continual typing (R. Jouvent, C. Bustarret, E. Gentaz) and prove the important cognitive benefits from pen writing, the others, like A. Trubek from Oberlin College in Ohio, tell that typing allows us to go faster, not because we want everything faster in our hyped-up age, but for the opposite reason: we want more time to think (The Guardian, 2017).

A tendency for sending physical letters seemed to have passed away forever. There are not many opportunities at university to write by hand - it's long, tiring and ineffective. Instead, digital writing is used at study and work we make notes, lead correspondence and receive acknowledgments via electronic devices. Writing an essay by hand becomes a real problem for young people who might need it at final exams or by some university admission regulations, when taking international exam in English etc. After 800 years of tradition, Cambridge University considers allowing laptops to replace pen and paper for exams (Busby, 2017).

We do not make statements but only try to find new ways of engaging students into process of study (grammar, in particular) by modern means, which are close to their world and interests. We've asked 10 of them on «What is grammar accuracy to you?» and received the answers which contained a common ideas of oral and written competence, ability to interact in a grammatically correct manner, to spot flaws, a skill to sound clearly at verbal level and, as a result, be perceived by others as professionals and welleducated people. Some students mentioned that grammar is more important today than it was 20 years ago because there have appeared new ways of communication, like e-mailing, and it urges them develop writing skills, it is a criteria which helps make the first impression of interlocutor about you. From professional perspective, today we are more writing people than ever before: we send official and business letters; chat on-line; use direct messages; post on social networks; create blogs and write comments.

Deciding on the methods of teaching foreign grammar, educator chooses those that are close to young adults, may engage and motivate them to independent study: viber group discussion, blog writing, publication of posts, commenting to popular news and events. Taking into account all the above mentioned, we understand that education should be of practical validity.

New educational opportunities require Internet competence of a teacher who can choose the appropriate materials, advises on approved 
network platforms, explains the idea and strategy of on-line study and prevents from possible distant education failures. According to the results of survey, young students are more likely to fall under influence of internet content, the younger are the students the more supervision they need from pedagogue; Master degree students (adults) tend to be more educationally independent and are able to select necessary information on their own.

We like to be popular, feedback is among the main motivation criteria which affect educational potential. Using on-line platforms pedagogue creates an informal environment for additional practice, for group interaction and continual development.

To make the conclusion on effectiveness of social networks for improving grammar competence we applied method of experimental focus group of 15 people, of close language level and academic relevance. The responsible teacher started a viber-group and tried to organize its activity: a) give daily tasks; b) analyze answers; c) decide the pace; d) motivate.

The experiment lasted one month and it has become possible to make the following conclusions:

Teacher is an integrated unit of such method, and should be prepared for a non-stop guidance, he/she establishes and discusses viber-class rules; never forgets to check members' activity, is ready to ease arguments, and keeps order inside educational environment - very often students tend to bring non-formal on-line communication style to digital class, write inappropriate comments or fill up study space with unnecessary information;

- pace is among the vital criteria at "viber class», as its balance determines the results, students study the concept until they have mastered it. Some tasks need more time than others, it's important to give gap-days and chance to think twice, then share careful answers - it is experience that teachers students react quickly and to the point. Typical tasks may be boring, which is a reason of inattentiveness, teacher acts in accordance with group tendencies, and never is individual-oriented, but group-centered; collaborative learning forces students to work with others as they learn, apart from grammar competence they develop people tolerance;

- teacher's digital competence allows to apply different instruments: visual aids, matchings, questionnaires, quizzes, maps, situation modeling schemes; react and comment adequately to students' answers - it is important to have a constant feedback from teacher and understand progress;

- motivation always runs the process, and the teacher specifies advantages of such method, its accessibility, convenience, effectiveness. During study there may happen some misunderstandings among participants, as being active on-line student demonstrates his/her skills to the whole group thus, creation of a positive, tolerant atmosphere is under teacher's responsibility, some know better than the others - so, competition is always there, and causes student's insecurities and doubts; creative mind is another challenge, especially for those who were seldom asked to use it at classes; comparison of own knowledge with the others' may provoke despair and apathy 
which should be overcome with the help of a teacher; find a way to make learning meaningful - personally relevant or relatable.

Blogging is another great study opportunity for students, it opens up talents to the world, they may write about things they like: music, films, relations, technologies, cookery, learning, business, money matters etc. It has been 25 years since the first blog appeared in 1994; in the late 2000s, the blogging sphere started expanding rapidly, and that growth has not slowed down to this day; it has been reported that in 2017, there were 350 million blogs on Tumblr; there are about 505 million blogs today; around 5.8 million blog posts are published daily (Aleksandar, 2019). Improving grammar skills this way you receive advantages of developing self-promotion skills, self-presentation competence, digital proficiency, reflection, critical thinking, etc.

Most of the teachers believe that Facebook is a disturbance in the classroom, but Facebook has the potential to be a learning tool when it's used strategically and creatively («Facebook as a Learning Tool», 2018). It takes the function of connector among people. Followers take the part of audience - so, why not to use the platform and share ideas. Writing posts as a study method makes you verbally careful, precise, mindful and prognostic, we call it «active learning» or «learning via activity»; reading your post, people have longer time for perception and comprehension.

Conclusion. The results obtained from the experiment have proved the effectiveness of using digital environment and social networks, in particular, for the development of grammar competence in foreign language teaching. All the participants of study have demonstrated improved grammar skills under careful and thoughtful pedagogical support. Staying active on-line students bring informal communicative style to virtual classroom, which requires specific coordination from a teacher, explanation on correct organization of interpersonal dialogue.

Personal motivation is among the basic advantages of using social media at study, we become open to the world, our close and distant acquaintances, which makes us more attentive and responsible to What and How we write; we try to demonstrate progress and receive positive feedback from readers; we learn to promote professional skills and competences.

\section{Bibliography}

Lukianova, Larysa \& Tovkanets, Hanna \& Sotska, Halyna \& Trynus, Olena (2019). Social and pedagogical aspects of virtual universities activity in the European educational space. Informatsiini tekhnolohii $i$ zasoby navchannia.

https://journal.iitta.gov.ua/index.php/itlt/article/view/2892 (in Ukrainian)

Salikin, Hairus \& Bin Tahir, Saidna. (2017). The Social Media-Based Approach in Teaching Writing at Jember University, Indonesia. International Journal of English Linguistics. 7. 3.4. http://www.ccsenet.org/journal/index.php/ijel/article/view/66299 (in English) 
Yunus, Melor \& Salehi, Hadi \& Chenzi, Chen. (2012). Integrating Social Networking Tools into ESL Writing Classroom: Strengths and Weaknesses. English Language Teaching. 5. 42. 10.5539/elt.v5n8p42. (in English)

Alba Rodríguez, Sánchez (2017). Developing Writing Skills Through Educative Social Networks. Univarsidad de Valladolid, 65 p. (in English)

Newnam, J. (2012). Technology's influence on education/South University Blog. Retrieved from: https://www.southuniversity.edu/whoweare/newsro om/blog/technologys-influence-on-education-76874 (in English)

Curtin, M. (2018). Are You On Your Phone Too Much? / Inc.com. - Retrieved from: https://www.inc.com/melanie-curtin/are-you-on-your-phone-toomuch-average-person-spends-this-many-hours-on-it-every-day.html (in English)

Hymas, Ch. (2018). A decade of smartphones: We now spend an entire day every week online / The Telegraph. - Retrieved from: https://www.telegraph.co.uk/news/2018/08/01/decade-smartphonesnow-spend-entire-day-every-week-online (in English)

Busby, M. (2017).Cambridge considers typed exams as handwriting worsens/ The Guardian.

https://www.theguardian.com/education/2017/sep/09/cambridge-

URL: considers-typed-exams-as-handwriting-worsens (in English)

Aleksandar, S. (2019). How Much Time Do People Spend on Social Media in 2019? / Techjury. - URL: https://techjury.net/blog/time-spent-on-socialmedia/\#gref (in English)

Essays, UK. (November 2018). Facebook As A Learning Tool. URL: https://www.ukessays.com/essays/education/facebook-as-a-learningtool-education-essay.php?vref=1 (in English) 